\title{
Taxing Peer-to-Peer Rental Services in Indonesia
}

\author{
Hadining Kusumastuti ${ }^{1 *}$, Titin Fachriah Nur ${ }^{2}$ \\ ${ }^{1}$ Tax Administration Laboratorium, Vocational Education Program Universitas Indonesia, Indonesia \\ ${ }^{2}$ Tax Administration Laboratorium, Vocational Education Program Universitas Indonesia, Indonesia \\ *Email: hadining.kusumastuti@gmail.com
}

\begin{abstract}
This descriptive analysis examines the difficulties of taxing income from online peerto-peer rental services (e.g., Airbnb, Airy Rooms) in Indonesia. We collect and review data from scholarly and professional literature and documents. Our discussion reveals that Indonesia's selfassessment system whereby taxpayers calculate, report, and pay their tax obligations is problematic because digital peer-to-peer businesses lack clear regulation. Indonesia needs to revamp its tax laws to suit digital transactions in the sharing economy. The article provides insights into steps that need to be taken.

Keywords: digital economy, sharing economy, peer-to-peer rental, tax on digital economy, taxation
\end{abstract}

\section{Background}

In the past decade, the "sharing economy" has grown through digital mediation-i.e., acquiring or exchanging goods, services, knowledge, and experiences with others online. From a business standpoint, a key element of the sharing economy is replacing ownership with access (PWC, 2015). Online peer-to-peer platforms allow private individuals to collaborate in using inventory. Consumers enthusiastically have adopted the services of such platforms as Airbnb, Gojek, RedDoorz, and Airy. Exponential growth of peer-to-peer platforms is possible by technological innovation and supply-side flexibility. Technological innovation streamlines market entry for suppliers, feeds consumer access to information, and reduces overhead supply. This study examines how difficulties the Indonesian government faces in taxing online peer-to-peer rentals, focusing on Airbnb, a $\$ 30$ billion pioneer in the sharing economy that has served 50 million guests since its inception in 2008.

\section{Research Objectives}

This research explains how Indonesian tax law fails to encompass peer-to-peer rental services in a sharing economy.

\section{Research Urgency}

This research is meaningful for several parties, notably:

a. Government

It informs the Indonesian government about impediments to taxing online peer-to-peer rental services and how to overcome them.

b. Taxpayers

It discusses taxes arising from a peer-to-peer rental services.

\section{Literature}

\subsection{Digital Market}

Characteristics of digital markets defined in the OECD model include:

a. Direct network effects: Utility from consuming a good or service from digital markets often depends on the number of other end-users consuming it.

b. Indirect network effects: These arise in multi-sided markets when one set of end-users (users of the social network) benefits from interacting with another set (advertisers on the social network). Online platforms offering rental accommodations, transportation, or peer-to-peer e-commerce are examples. 
c. Economies of scale: Making goods and services available digitally may entail relatively high fixed costs and far lower variable costs. Developing software, for instance, requires considerable investment in infrastructure and labor, but once finalized a program can be maintained, sold, or distributed at low marginal cost.

d. Switching costs and lock-in effects: End-users might own devices with operating systems that are incompatible with those of networks they wish to access. If so, customers may be reluctant to buy devices with compatible operating systems because of psychological or monetary switching costs.

e. Complementarity: Many goods and services traded in digital markets are complements, and customers increase utility by consuming two or more complementary goods together.

\subsection{Sharing Economy}

Digitalization facilitates the sharing economy, or collaborative consumption. The sharing economy is not new, but technology has lowered transaction costs, made more information available, and enhanced transaction reliability and security. Numerous applications involving diverse business models now offer services or products such as cars, spare rooms, food, clothes, and private jets. Most digital participants in the sharing economy do so not to earn a living but to entertain relationships, advance a cause, or to make ends meet. Earning supplementary income is a net benefit that often requires little quantitative cost-benefit analysis. Non-professional providers generally share their personal resources at lower prices than professionals, thereby reducing overall prices, including those of professionals.

\section{Methodology}

We employ descriptive research by reviewing and assessing secondary data collected from scholarly and professional literature and documents.

\section{Results and Discussion}

Our research reveals that Indonesia lacks statutes for taxing online peer-to-peer rental services. Current regulations related to digital transactions fall under SE-62/PJ/2013 on the Affirmation of the Taxation Provisions on e-Commerce Transactions. Therein the Indonesian government acknowledges that e-commerce differs from brick-and-mortar transactions only as a mode of trading. It acknowledges no other general difference between them.

SE-62/PJ/2013 merely sets a model for e-commerce transactions. That model features an online marketplace, classified ads, daily deals, and online retailing. It defines terminology for e-commerce transactions, flowcharts, business processes, and aspects of taxation. The model for e-commerce transactions in SE$62 / \mathrm{PJ} / 2013$ differs from the model that features peer-to-peer transactions between individuals. Therefore, SE$62 / \mathrm{PJ} / 2013$ cannot be the legal basis for taxing peer-to-peer transactions.

Indonesia's is a self-assessment system of taxation. Government trusts each taxpayer to calculate, report, and pay obligations owed. Like all self-assessment systems, Indonesia's relies on taxpayers' ability to understand their obligations and on their conscientiousness in meeting them. Digital peer-to-peer rental services challenge Indonesia's mechanism for taxing digital transactions.

Regulations should define taxable transactions clearly so all parties know when taxes apply and tax administrators can monitor compliance. Regulations should be simple to understand, honor, and monitor. Tax burdens should apply equitably to similar types of transactions whether conventional or digital.

\section{A. Challenge in Taxing Peer-to-peer Rental Services}

Taxing peer-to-peer rental transactions involves challenges to be met and consequences to be avoided.

a. Tax art 21/23 makes it impossible to impose withholding on homeowners offering Airbnb-style rentals if they are not resident taxpayers in Indonesia.

b. Self-assessment makes it difficult to identify renter-homeowners and taxes owed on income from peer-to-peer digital transactions.

c. Indonesia's Directorate General of Taxation needs to create systems to facilitate taxing peer-topeer rental transactions.

d. Taxation should not to kill growth in peer-to-peer rental businesses.

e. Compliance burdens for taxpayers should not encourage tax avoidance. 
f. Digital transactions thrive from difficulty identifying sellers, customers, and amounts paid. Difficulty accessing such information is exacerbated if customers and homeowners offering peerto-peer rentals are in different jurisdictions.

In short, the challenge is to assure equitable, accurate, and visible taxation of online peer-to-peer rental services without destroying them as an economic activity or imposing overwhelming compliance burdens.

\section{B. Addressing Challenges in Taxing Peer-to-peer Rental Services}

Challenges for tax administrators raised by online peer-to-peer rentals include collecting information about participants and amounts paid and resolving jurisdictional questions about where tax liability falls. Options for meeting these challenges include taxpayer education and gathering information directly from online platforms. Both approaches are discussed below.

\section{a. Improving taxpayer education and self-reporting}

Providers of services such as Airbnb seldom have contracts or sustained business relationships with clients, so collecting taxes on their rental income depends on taxpayers' declaring it on their tax returns. Whether they do so is a question of conscience-providers know their transactions are largely undetectable - and education: they might not realize that income from a sideline or online business is taxable.

\section{b. Educating taxpayers about obligations arising from the platform economy}

Through its website (www.pajak.go.id), Indonesia's Directorate General of Taxes can educate taxpayers about taxes owed on income from online peer-to-peer rental services.

\section{Taxing Income from Peer-to-peer Rental Services According to Indonesian Tax Regulations}

The Government of Indonesia does not yet have a special regulation in taxing peer to peer rental services. Especially for peer to peer rental services in accomodation such as Airbnb, Airyroom and so on, when viewed from its business activities which is a rental inn like a rental house, hotel or inn. So that, in accordance with the provisions of the existing tax laws in Indonesia, the income received from peer to peer rental services such as Airbnb is included in the category of income on the lease of land and/or building. The following tax treatment of activities in respect of land lease and/or building is reviewed from the side of the recipient of rental income and the tenant refers to the applicable taxation provisions, namely:

- Act no. 36 Year 2008 About Income Tax

- Law no. 28 Year 2009 on Regional Taxes and Levies

- Government Regulation no. 34 Year 2017 on Income Tax on Income from Land and / or Building Rental.

The types of rentals provided by Airbnb are vary, from rental of houses, apartments, rooms, condominiums, hotels, villas and so on, making it difficult to determine the type of tax on lodging services via Airbnb. Accomodation services through Airbnb includes categories of activities in respect of land and/or building rentals under the provisions of Article 4 paragraph (2) of Law no. 36 Year 2008 About Income Tax. Article 2 paragraph (3) of Government Regulation no. 34 Year 2017 on Income Tax on Income from Land and/or Building Rental stipulates that the income received or obtained from the accommodation services and its relates, does not include income from the land and/or building rental as per stipulate under the provisions of Article 4 paragraph (2) of Law no. 36 Year 2008 About Income Tax. In the explanation of Article 2 paragraph (3) of Government Regulation no. 34 Year 2017, the category of Lodging Services is in the form of rooms, dormitories for students/students, dormitories or workshops and boarding houses. So that the income received from the service of accommodation via Airbnb shall be the object of the Final income tax refers to the provisions of Government Regulation no. 46 of 2013 jo Government Regulation no. 23 of 2018 on Income Tax on Income from Business Received or Obtained by Taxpayers with Specific Gross Distribution. Definition of the Hotel according to Article 121 Law No.28 of 2009 on Regional Taxes and Levies is a lodging/lodging service facility including other related services with a fee, which includes motels, guesthouses, tourism huts, tourist homes, boarding houses, lodging houses and the like, as well as boarding house with more than 10 (ten) rooms. 
Based on the above description, the following tax treatment of accomodation services via Airbnb is as follows:

a. Object of Final Income Tax Article 4 paragraph (2) letter d Act no. 36 Year 2008 About Income Tax.

If the type of rental lodging in the form of homes, apartments and condominiums. On income refers to the provisions of income tax is subject to Final Income Tax with a rate of $10 \%$.

b. Object of Final Income Tax Article 4 paragraph (2) letter e Act no. 36 Year 2008 About Income Tax jo Government Regulation no. 46 of 2013 jo Government Regulation no. 23 Year 2018 About Income Tax on Income from Business Received or Obtained by Taxpayers Having Certain Gross Distributions.

If the type of rental of the lodging includes the category of accommodation services and accommodation. On income refers to the provisions of income tax is subject to Final Income Tax with a rate of $1 \%$.

c. Hotel Tax Object Article 32 Act no. 28 Year 2009 on Regional Taxes and Levies

If the type of rental of the lodging is included in the definition of the hotel as provided for in Article 1. On income referred to in this area tax shall be subject to Hotel Tax with a rate of $10 \%$.

\section{Conclusion}

The imposition of tax on peer to peer rental services, especially on lodging services via Airbnb becomes a challenge for the Government of Indonesia, in this case the Directorate General of Taxation considering the tax potential of the type of digital economy transactions become higher. Type of lodging offered via Airbnb various types, so in the imposition of taxes must be identified type of lodging owned by the owner of lodging services in determining the imposition of tax. So, it takes the role of government in educating the tax aspects of lodging services via peer to peer rental services.

\section{References}

Aslam, A., \& Shah, M. A. (2017). Taxation and the peer-to-peer economy. International Monetary Fund.

Bloch, F., \& Demange, G. (2018). Taxation and privacy protection on Internet platforms. Journal of Public Economic Theory, 20(1), 52-66.

Bourreau, M., Caillaud, B., \& De Nijs, R. (2018). Taxation of a digital monopoly platform. Journal of Public Economic Theory, 20(1), 40-51.

Crémer, J. (2015). Taxing network externalities. Taxation and the digital economy: A survey of theoretical models.

Davies, A. R., Donald, B., Gray, M., \& Knox-Hayes, J. (2017). Sharing economies: moving beyond binaries in a digital age. Cambridge Journal of Regions, Economy and Society, 10(2), 209-230.

http://www.hbs.edu/faculty/conferences/2016dids/Documents/Fraigerber_Sundararajan_March2016.pdf

https://diodeweb.files.wordpress.com/2017/08/diwkppr68-diode.pdf Defining, Conceptualising and Measuring the Digital Economy RUMANA BUKHT \& RICHARD HEEKS

https://www.theseus.fi/bitstream/handle/10024/120287/Rakovets_Elizaveta.pdf?sequence=1\&isAllowed=y, 2016

OECD. (2015). Addressing the Tax Challenges of the Digital Economy, Action 1 - 2015 Final Report, OECD/G20 Base Erosion and Profit Shifting Project, OECD Publishing, Paris, http://dx.doi.org/10.1787/9789264241046-en.

Pachenkov, O., \& Yashina, A. (2017, September). When sharing economy meets digital one: Towards understanding of new economic relations. In Proceedings of the Internationsl Conference on Electronic Governance and Open Society: Challenges in Eurasia (pp. 91-98). ACM.

Ravenelle, A. J. (2017). Sharing economy workers: selling, not sharing. Cambridge Journal of Regions, Economy and Society, 10(2), 281-295.

Tax Challenges Arising From Digitalisation-Interim Report 2018 @ OECD 2018

The Rise of the Sharing Economy: Estimating the Impact of Airbnb on the Hotel Industry, 2016

Thebault-Spieker, J., Terveen, L., \& Hecht, B. (2017). Toward a geographic understanding of the sharing economy: Systemic biases in UberX and TaskRabbit. ACM Transactions on Computer-Human Interaction (TOCHI), 24(3), 21. 